Marquette University

e-Publications@Marquette

$1-1-2014$

\title{
Are Houses Too Big or In the Wrong Place? Tax Benefits to Housing and Inefficiencies in Location and Consumption
}

David Albouy

University of Illinois at Urbana-Champaign

Andrew Hanson

Marquette University, andrew.r.hanson@marquette.edu

Published version. Tax Policy and the Economy, Vol. 28, No. 1 (2014): 63-96. DOI. (C) 2014 University of Chicago Press. Used with permission. 


\title{
Are Houses Too Big or In the Wrong Place? Tax Benefits to Housing and Inefficiencies in Location and Consumption
}

\author{
David Albouy, University of Illinois at Urbana-Champaign and NBER \\ Andrew Hanson, Marquette University
}

\section{Executive Summary}

Tax benefits to owner-occupied housing provide incentives to consume housing, offsetting weaker disincentives of the property tax. These benefits also help counter the penalty federal taxes impose on households who work in productive high-wage areas, but reinforce incentives to consume local amenities. We simulate the effects of these benefits in a parameterized model, and determine the consequences of various tax reforms. Reductions in housing tax benefits generally increase efficiency in consumption, but reduce efficiency in location decisions, unless they are accompanied by tax rate reductions. The most efficient policy would eliminate most tax benefits to housing and index taxes to local wage levels.

Keywords: Federal taxation, general equilibrium tax incidence, geographic inequality, locational efficiency, mortgage interest deduction, cost of living, tax reform.

JEL Classification: H24, H5, H77, R1.

\section{Introduction}

Since its inception, the federal tax code has given preferred status to housing, particularly housing occupied by owners. Today, this preferred status manifests itself in several ways. First and foremost, owneroccupiers do not report imputed housing rents - that is, rents they effectively receive as their own landlords - as taxable income. Yet, mortgage interest costs up to $\$ 1$ million of debt on primary and secondary homes are deductible from taxable income. ${ }^{1}$ Second, capital gains from home sales of up to 
$\$ 500,000$ for married couples, and $\$ 250,000$ for singles, are excluded from taxable income. The Office of Management and Budget (OMB) projects that these benefits to home owners will result in foregone tax revenues-or "tax expenditures" - for the 2014 fiscal year of over \$200 billion, ${ }^{2}$ equal to $14 \%$ of federal income tax revenues. ${ }^{3}$ Similar tax expenditures cost state governments billions of dollars in foregone income tax revenues. There are also implicit reductions in sales tax revenues, as new homes and home improvements are not subject to sales taxes. ${ }^{4}$

Recent shortfalls in government revenues and increases in top marginal tax rates have caused some policymakers to question whether the preferred treatment of housing should be revoked in order to raise revenues or lower marginal rates (e.g., Bartlett 2013). In 2005, the President's Advisory Panel on Tax Reform proposed replacing the mortgage interest deduction (MID) with a 15\% credit, and limiting applicable mortgages based on regional housing prices. Similar ideas have been echoed in the tax reform proposal put forth in 2010 by the National Commission on Fiscal Responsibility and Reform (i.e., the "SimpsonBowles Commission"). ${ }^{5}$ The recent boom and bust of housing prices and its impact on the economy has further raised awareness of the tax treatment of housing. Many economists believe that eliminating the mortgage-interest deduction would deleverage investments in housing and lead to greater housing price stability (e.g., Green 2011). At the same time, policymakers remain leery of reforming housing tax benefits while prospects for the housing market and the general economy remain uncertain.

Housing-related tax reforms tend to be quite popular with economists, and unpopular with the public at large. In a recent National Tax Association (NTA) poll of tax economists, 77\% favor repealing the MID (Michigan News 2013). A poll of real estate economists and similar experts by Zillow indicates that a majority want to repeal the MID; only $11 \%$ favor keeping the MID in its current form (Pulsenomics 2012). The electorate seem to want to keep tax benefits for housing: the NTA poll found that only $10 \%$ of the public favors repealing the MID. In a United Technologies (2013) poll, 61\% of Americans indicate that it is "very important" to preserve the MID, holding it in higher regard than the deduction for charitable contributions. The support for the MID in polls is somewhat surprising, as only $24 \%$ of tax filers in 2011 deducted any mortgage interest on their tax return. ${ }^{6}$ In a more nuanced poll by Pew (2012), the public was evenly split on whether the MID should be limited in order to reduce the debt. Unless economists have different 
values than the population at large, the tax treatment of housing may be an issue where better understanding could bridge the gap in opinion, making policy reforms more realistic.

The consequences of housing's tax-preferred status have received considerable attention in the economic literature (see Rosen (1979a), Mills (1987), Poterba (1992), Green and Reshovsky (1999), and Hanson (2012) for examples). Housing benefits are distributed regressively, with high income households receiving greater benefits because of their high rates of home ownership, more expensive houses, and higher marginal tax rates (see Poterba and Sinai 2011). In theory, lowering the cost of housing through tax benefits could encourage home ownership, which some argue produces positive externalities worthy of subsidization. Home ownership seems to increase exterior maintenance and voter participation, and may benefit children (see Glaeser and Shapiro (2003) for a summary). The limited scope of externalities considered in these studies makes the case for large subsidies tenuous, as does the empirical evidence that tax benefits in their current form do little to encourage home ownership (e.g., Hanson 2012).

Most of the literature on the consequences of housing tax benefits focuses on how they affect investment in housing capital, its price, and the leveraging of mortgage debt. These studies sometimes ignore how property taxes discourage the consumption of housing if buying a larger home does not result in proportionately larger benefits in local services paid for by those taxes. Furthermore, they usually ignore the preferential sales tax treatment of housing, discussed in Hall (1996).

Far less attention has been given to the issue of how housing tax benefits may influence where households choose to live, work, and enjoy local amenities. Gyourko and Sinai $(2003,2004)$ demonstrate that the geographic distribution of housing tax benefits is strongly tilted toward areas where housing prices, income levels, and home ownership rates are high, and that this distribution is quite stable over time. However, providing the distribution of benefits does not show how location choices are influenced by these benefits, or how they operate in the larger context of a location-distorting income tax. Albouy (2009a) argues that taxes on labor income discourage households from living in places where wage levels are high, while tax benefits encourage households to live where price levels are high. Tax benefits to housing implicitly provide a form of cost-of-living adjustment in the federal tax code. Such an adjustment may offset disincentives to live in high-wage areas if price levels are positively related to wages, or magnify them if prices 
are negatively related to wages. A positive relation will occur when price variation is driven by the relative productivity of firms, while a negative relation will occur when prices are driven by relative differences in quality-of-life amenities. As a result, tax benefits to housing will mitigate the tax penalty of working in an area with better-paying jobs, but augment the implicit tax subsidy given to workers who accept lower pay to live in the most desirable areas.

Empirically, wage and price levels exhibit a strong positive correlation across American metropolitan areas. As a result, indexing taxes to local costs-of-living tends to reduce locational inefficiency by reducing tax burdens in high-wage areas, albeit imperfectly. Thus, tax benefits to housing generally improve efficiency of location choices, even though they reduce efficiency of housing investment and consumption choices.

Besides considering the impact on location, this chapter makes a number of other additions to the literature on the tax benefits to housing. We estimate the degree to which housing may be inefficiently consumed relative to nonhousing goods by taking into account property taxes on housing and sales taxes on nonhousing consumption. In addition, we relax the typical assumption of perfectly elastic housing supply. Instead, we incorporate local variation in the elasticity of housing supply to provide more accurate measures of efficiency costs in housing consumption and worker locations. We also consider how tax reforms, such as eliminating benefits for housing or indexing taxes to local wage levels, would affect local housing costs, employment, and the efficiency of housing consumption and locational choice across the country. ${ }^{7}$

Our simulation results imply that the existing system of income taxation with tax benefits to housing caused the typical house to be $4 \%$ too large in 2007, creating an annual deadweight loss of $\$ 7$ billion. ${ }^{8}$ Without any tax benefits in the income tax code, houses would instead be $2 \%$ too small because of property taxes, causing an efficiency loss of $\$ 2$ billion. Our simulations show that $15 \%$ of the population is inefficiently located at a cost $\$ 26$ billion annually. Eliminating the mortgage interest and property tax deductions would reduce the inefficiency cost in housing consumption by about $\$ 3.5$ billion, and increase the inefficiency cost from locational choices by less than $\$ 1$ billion, so that on net such a reform would improve efficiency. Eliminating the favorable capital gains treatment in addition would produce no additional gains, as costs in inefficient location choices would offset any further reductions in consumption inefficiency. More efficient reforms would eliminate housing benefits 
altogether and deflate taxable income by local costs-of-living or local wage levels.

The remainder of the paper begins with a presentation of models that incorporate income taxes into location and housing consumption choice. The models produce equations for the deadweight loss caused by the tax code's interaction with these markets. We then calibrate the models using data on wages, home prices, and location characteristics from the American Community Survey (ACS) and the Internal Revenue Service ZIP code file. We use the calibrated model to present deadweight loss estimates under the current income tax regime and simulate the deadweight loss effects of several tax reforms.

\section{Modeling Locational and Housing Consumption Inefficiency}

\section{A. How Taxes Alter the Location Choice Decision}

We model the relationship between taxes, housing benefits, and location choice using the general equilibrium framework of Albouy (2009a), which adds federal taxes to the Rosen (1979) and Roback (1982) model of wages, amenities, and housing costs. In this framework, households must purchase housing in the city where they live and work; cities are effectively metropolitan areas. We assume that households are fully mobile across cities and have homogenous tastes. Firms hire labor, capital, and land to produce local housing goods, as well as goods that are tradable across cities, which we assume have the same price everywhere. The second main assumption is that these firms make zero profits, paying factors their marginal products. These strong equilibrium assumptions make the framework best suited for understanding outcomes over the long run and when applied to crosssectional data.

Cities vary in two essential attributes, the productivity of their firms, and the quality of life they offer to residents. Through the twin assumptions that households are mobile and firms make zero profits, firm productivity and quality of residential life simultaneously determine housing prices and wages in each city. Because households are mobile, they will pay more for housing in cities where wages are high or where quality of life is exceptional. Firms will pay higher prices for land in areas where wages are low, or productivity is high.

We demonstrate this model and its consequences for the distortionary effect of taxes in figures 1 and 2, in a simplified setting where we equate 


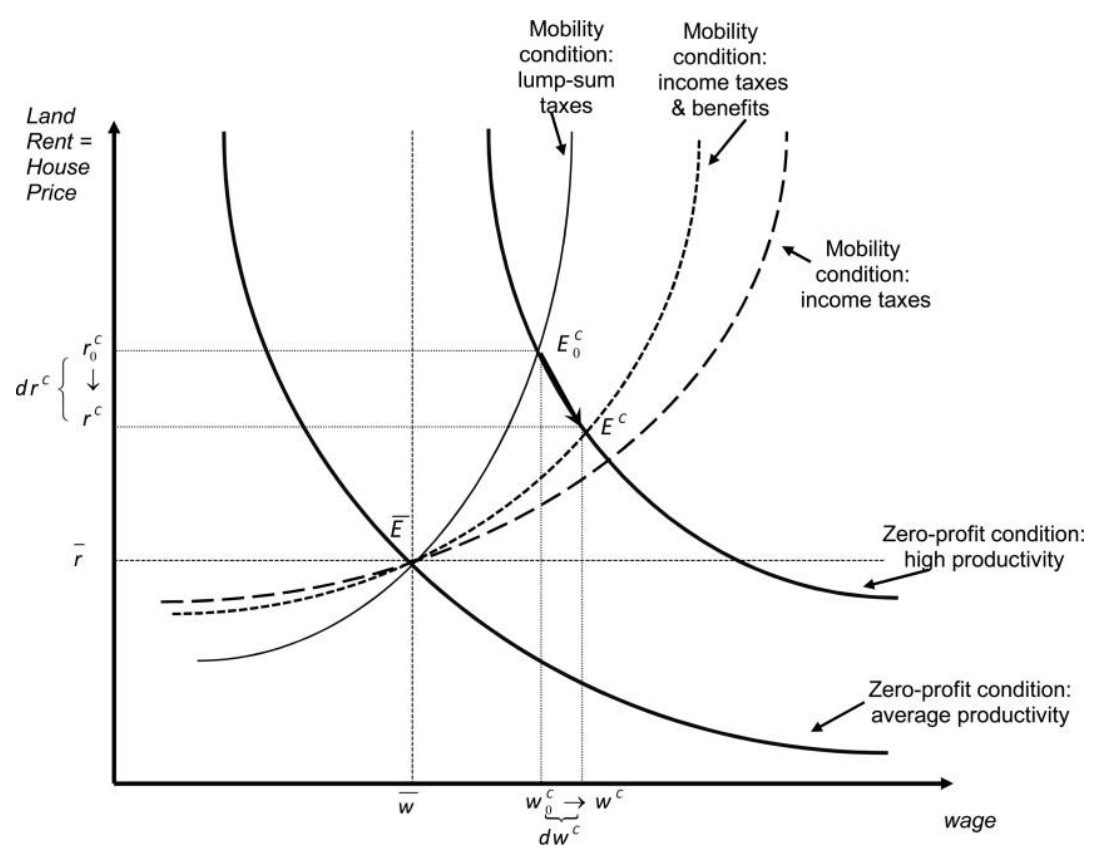

Fig. 1. Equilibrium prices and wages in cities that vary in productivity with income taxes and housing benefits: Nashville and Chicago

housing purchased by households with land purchased by firms. ${ }^{9}$ Figure 1 illustrates the case for cities that vary in productivity. Consider two cities, Nashville and Chicago. Both cities offer the national average quality of life, but Chicago has above-average productivity. Each city has downward-sloping zero profit curves for firms, as firms bid less for land in cities with higher wages. Chicago's zero profit curve is above Nashville's, as firms pay more to be in a highly productive area. The mobility condition for workers slopes upward, as workers bid more to live in cities where wages are high. The intersection between the zero-profit and the mobility conditions, that is, the bid curves for firms and households, determines the equilibrium prices and wages. More productive cities, like Chicago at $E_{0}^{C}$, offer higher wages and charge higher prices, than in less productive cities, like Nashville at $\bar{E}$.

Federal taxes on wages reduce the net earnings a worker gains when moving from a low-wage to a high-wage city. This reduces the willingness to pay of households to live in higher wage cities. In the graph, income taxes rotate the mobility condition clockwise. If we compare the effect of an income tax relative to a neutral lump-sum tax, the rota- 
tion occurs through Nashville, since Nashville pays the same amount with either tax. ${ }^{10}$ Therefore income taxes increase the equilibrium wage and reduce the equilibrium price in Chicago relative to Nashville. When there is any elasticity in the supply or demand for local land, federal taxes also cause the equilibrium population in Chicago to fall. These losses are offset by higher population levels in places with below-average productivity. ${ }^{11}$

The location distortion from income taxes may be undone by indexing federal taxes to local wage levels. Suppose that a typical advertising agent gets paid $\$ 60,000$ in Nashville and $\$ 90,000$ in Chicago. Agents face a flat marginal tax rate of $33.3 \%$ on labor income. To simplify matters, suppose government revenues are redistributed lump-sum so that workers everywhere receive $\$ 20,000$. Then, an agent in Nashville pays on net zero to the government, but is subjected to a $\$ 10,000$ penalty for moving to Chicago, dulling her incentive to move there. An ideal wage index would tell us that advertisers are paid $50 \%$ more in Chicago. If taxable income was deflated using this index, then the advertiser would be taxed only on $\$ 60,000$ in Chicago, and not face any tax penalty for moving. ${ }^{12}$

Federal tax benefits to housing increase the bid households are willing to pay for higher wages or quality of life, since a higher bid results in a lower tax burden. Graphically, the mobility condition with housing benefits, shown by the shorter dashed curve in figure 1, is rotated counterclockwise relative to the zero mobility condition with income taxes. This moves the equilibrium wage back down and the price back up to $E^{C}$, producing an outcome closer to the initial neutral tax equilibrium at $E_{0}^{C}$. With a federal income tax in place, the housing tax benefit helps undo the tax distortion created by the income tax. Both the distortion from the income tax and the correction from housing tax benefits (assuming it is a deduction) increase with a household's marginal tax rate.

Following the example of the advertising agent above, consider that she pays $\$ 20,000$ more a year for a house in Chicago relative to a comparable one in Nashville. Now suppose that three-quarters of this amount can be deducted from her income taxes (some taxes on labor income, such as payroll, do not allow for such deductions). Then, the agent would receive one third of $\$ 15,000$ back in her taxes, $\$ 5,000$ helping to offset the $\$ 10,000$ income tax penalty from working in Chicago. If housing is the only good that varies in price across cities, then a $100 \%$ deduction of housing expenditures would completely undo the location distortions income taxes induce across cities that vary in productivity.

With more than one good that varies in price across cities, location 


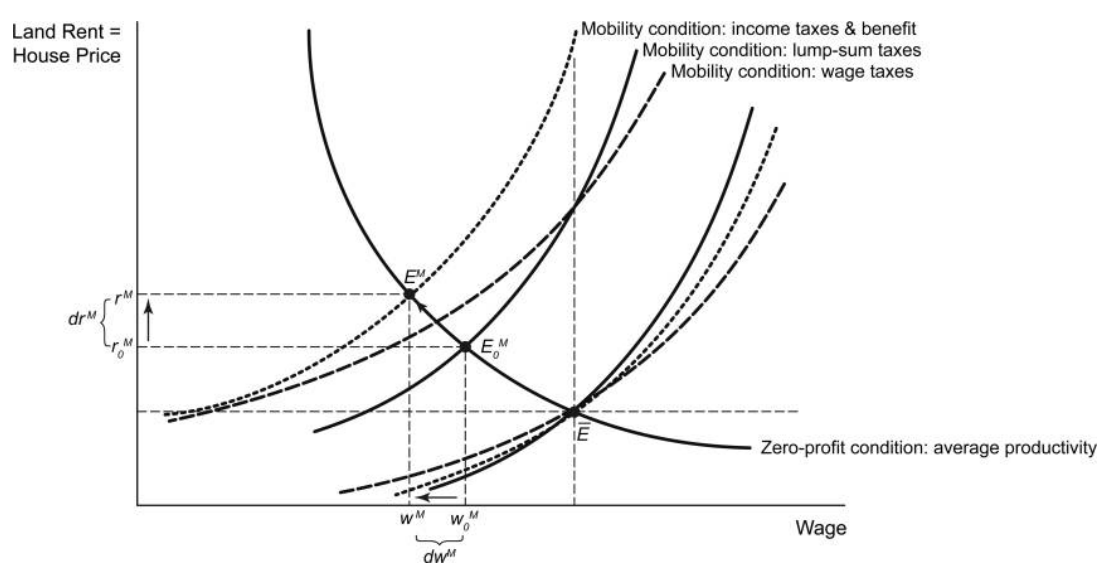

Fig. 2. Equilibrium prices and wages in cities that vary in quality of life with income taxes and housing benefits: Nashville and Miami

distortions of this kind could be undone by deflating income levels by an ideal cost-of-living index, which would reflect the cost households bear for locating in higher-wage locations. For the advertising agent, costs of living are one-third higher for the agent, as they offset her after-tax income gain of $\$ 20,000$ in Chicago relative to $\$ 60,000$ in Nashville (assuming she pays zero taxes net of her lump-sum refund). The tax system will be geographically neutral if workers with the same after-tax real incomes pay the same in taxes. Once in a tax-neutral equilibrium, a cost-of-living adjustment is fairly straightforward and equivalent to a wage-level adjustment. For example, say making taxes neutral lowers the agent's salary from $\$ 90,000$ to $\$ 87,000$ and raises her extra housing expenditures from $\$ 20,000$ to $\$ 27,000$. Both the cost-ofliving and wage index would then be $45 \%$ higher in Chicago than in Nashville.

When cities vary in quality of life, instead of productivity, cost-ofliving adjustments and tax benefits make location decisions less, rather than more, efficient. Figure 2 demonstrates how federal income taxes and housing tax benefits change the locational equilibrium for two cities that vary by residential quality of life. Miami has above average quality of life, and Nashville has average quality of life. Here, both Nashville and Miami share the same zero-profit condition for firms, as they both have average productivity. Because quality of life is higher in Miami, households there bid more for the price of housing than in Nashville at every wage level. They are willing to consumer fewer di- 
rectly purchasable market goods to consume nonmarket goods, such as beaches and sunshine. Such nonmarket goods are scarce and indirectly paid for through the land market. Graphically, Miami's mobility condition is shifted up to reflect this higher bid. In equilibrium, nicer quality-of-life cities, like Miami, charge higher prices and offer lower wages than less desirable cities, like Nashville.

Federal taxes soften the pay cut that households endure for living in a nicer city. For example, a bartender that takes a $\$ 3,000$ pay cut to relocate from Nashville to Miami may only experience a $\$ 2,000$ pay cut after taxes. This income tax effect rotates the mobility conditions for both quality-of-life levels clockwise, from the case of a neutral lumpsum tax, around cities with average national wage. As in the previous example, house prices and wages remain stable in Nashville. However, in Miami home prices are bid up, and wages are bid down, as more residents migrate into the city from below average quality-of-life locations. Employers who locate in beach towns or other amenable locations are effectively offering their workers an untaxed fringe benefit. Workers end up passing this benefit on to landowners in the form of higher rents.

Tax benefits to housing increase the bid households pay in areas with higher quality of life, rotating the mobility condition counterclockwise around the average price level. In Miami, this further increases the price of housing and lowers the wage households are willing to endure to enjoy a higher quality of life. Across cities that differ in quality of life, tax benefits to housing exacerbate the spatial distortion caused by federal income taxes on labor. ${ }^{13}$

The formal model, detailed in Albouy (2009a), produces a federal tax differential for each city, defined as the additional taxes paid by household in location $j$ relative to the national average as a fraction of average income. It uses a representative household model, which under certain assumptions may be used to approximate the economy using an average of households weighted by their income. Differences in federal tax burdens across cities may be neatly approximated by log linearizing a federal tax schedule and applying the envelope conditions implied by household mobility and zero profits. This approximation produces the following locational "tax differential" or "tax distortion," expressed as a fraction of household income.

$$
\frac{d \tau^{j}}{m}=\tau^{\prime} s_{w} \hat{w}^{j}-f \sigma s_{h} \hat{p}^{j}
$$


Here, $m$ is average household income, $\tau$ ' is the marginal tax rate, $\hat{w}^{j}$ and $\hat{p}^{j}$ are log wage and price differentials relative to the national average, $s_{w}$ is the share of income from labor, $f$ is the fraction of itemizers, $\sigma$ is the percent reduction in housing costs, and $s_{h}$ is the share of income spent on housing. This value may be positive or negative, depending on whether a city pays more or less than the national average.

By making high-wage cities less attractive, federal taxes induce workers and businesses to move away from high-wage cities toward low-wage ones. This causes an efficiency loss from misallocating workers across areas. The employment effect of a differential tax can be written as $\Delta \hat{N}^{j}=\varepsilon^{j} \cdot d \tau^{j} / m$, where $\Delta \hat{N}^{j}$ is the change in log employment due to mobility, and $\varepsilon^{j}$ is the elasticity of local employment with respect to a local, uncompensated tax, written as a percent of total income. In principle, reduced-form estimates of this elasticity can be estimated or calibrated from a structural theoretical model.

Because workers locate in response to federal income taxes, the resulting spatial distribution of employment and population is inefficient, or "locationally inefficient" (Wildasin, 1980). Consistent with Harberger (1964), this deadweight loss, expressed as a fraction of national income, is proportional to half the size of the tax differential times the induced change in migration, averaged across cities.

$$
\frac{D W L}{\text { National Income }}=\frac{1}{2} E\left(\Delta \hat{N}^{j} \frac{d \tau^{j}}{m}\right)=\frac{\varepsilon}{2} \cdot \operatorname{Var}\left(\frac{d \tau^{j}}{m}\right)
$$

Whatever the distribution of city attributes, this formula captures the entire efficiency loss from all of the distortions created by unequal geographic taxation, including the indirect distortion on the location of capital. This equation assumes that city attributes are unaffected by city population levels.

If housing is the only local good, providing a full cost of living adjustment by indexing taxable income to local price levels would be equivalent to setting $f=1, \sigma=\tau$ ' in equation (1). In this case, only differences in real incomes would be taxed. In equilibrium, this would occur only across households in cities that vary in quality of life. In other words, a full cost-of-living indexation would eliminate the tax incentive to leave productive cities for unproductive ones, but would preserve the incentive to leave low quality-of-life cities for high quality ones. In effect, the tax benefits to housing provide a partial cost-of-living index for those who claim it. Replacing the tax benefits to housing with an equiv- 
alent partial cost-of-living index would create similar incentives for renters and nonitemizers. It would also reduce the marginal incentive to consume housing, discussed in the next section.

To completely prevent taxes on labor from distorting location decisions, taxable labor income would need to be indexed by an ideal measure of local wage levels. Such an index should account for how the income of workers depends on where they live, and effectively control for local characteristics of the workforce. As households are inherently different, producing such an index would be difficult. Empirically, however, wage rates across different types of workers by education, experience, gender, race, and occupation do appear to be strongly correlated across cities.

\section{B. How Taxes Alter the Housing Consumption Decision}

Here we consider how tax benefits affect housing consumption relative to other kinds of consumption, in a partial equilibrium setting. Besides taking into account federal housing benefits, we also incorporate state and local policies that are rarely considered at the same time. The most important of these are local property taxes, which matter if they act as an excise tax on the margin. We also consider the absence of sales taxes on new housing purchases or the labor component of improvements.

We begin with how taxes affect the effective price of additional housing, for example, the incentive to consume additional square footage or a second bathroom, within a given neighborhood. The effective ad valorem subsidy created for housing consumption in area $j$ is:

$$
\sigma_{j}=\left(1-U C_{\text {Preferred }} / U C_{\text {Neutral }}\right)+\tau_{S}
$$

where $U C_{P_{\text {referred }}}$ is the user cost of housing with special tax considerations, $U C_{\text {Neutral }}$ is the user cost of housing without them, and $\tau_{S}$ is the state sales tax. ${ }^{14}$

To calculate the user cost of housing with and without special treatment in the tax code we use a model similar to Poterba and Sinai 2008 and $2011 . .^{15}$ This user cost model adds to previous versions by considering the housing-specific risk premium as a cost to borrowers, while recognizing that buyers benefit from the reduction in risk associated with being able to prepay or default. ${ }^{16}$ Thus, the model excludes the mortgage interest rate in excess of the risk-free rate as a cost. Our notax baseline is the user cost of housing without differential tax treatment, removing the mortgage interest deduction, property taxes, and 
taxing capital gains. The user cost model without differential tax treatment for housing is:

$$
U C_{\text {Neutral }}=r_{T}+\beta+m+d-\left(1-\tau_{C G}\right) \pi
$$

where $r_{T}$ is the risk-free interest rate, $\beta$ is a housing specific risk premium, $m$ is annual maintenance and $d$ is depreciation costs. In keeping tax neutral treatment, we include a tax on housings capital gain. The capital gain itself is represented by price inflation, $(\pi)$, and is subject to the capital gains tax rate, $\tau_{C G}$.

To see how changing the tax treatment of housing creates deadweight loss, we also need a variant of the user cost model that reflects current law tax treatment. We add in property taxes, the mortgage interest deduction, as well as the deduction for property taxes to the user cost equation in (4). In adding the differential tax parameters, we consider that the full mortgage interest rate is deductible ${ }^{17}$ while only the interest rate in excess of the risk-free rate is a cost. We also consider that property taxes may be considered as either excise taxes or benefit taxes. See Miezkowski (1972) for a full explanation of the excise view of property taxes; also see Zodrow (2001) for an explanation of the difference (and reconciliation) of competing views of property taxation. ${ }^{18}$ With these considerations, and current tax treatment, the user cost of housing with preferential tax treatment is:

$$
\begin{aligned}
U C_{\text {Preferred }}= & \left(1-\left\{\tau_{D}(1-s) \lambda+\tau_{Y}(1-\lambda)\right\}\right) r_{T}+\left(1-\tau_{Y}\right) \beta \\
& -\tau_{D}(1-s) \lambda\left(r_{M}-r_{T}\right)+m+\left(1-\tau_{D}-k\right) \tau_{P}-\pi
\end{aligned}
$$

where $\tau_{Y}$ is the marginal income tax rate applying to investment income, ${ }^{19} \lambda$ is the share of the home financed with debt, $\tau_{D}$ represents the marginal income tax rate applying to deductions, $r_{M}$ represents the mortgage interest rate, and $\tau_{P}$ is local property taxes. We also include the current limit on mortgage interest deductibility, set at $\$ 1$ million in the $s$ parameter. This parameter follows Anderson, Clemens, and Hanson (2007), and represents the average share of mortgage that exceeds the current law cap. The parameter, $k$, also an innovation to the user cost model added by Poterba and Sinai (2011) allows flexibility in viewing the property tax as a benefit tax or an excise tax. If the property tax is completely a benefit tax, then $k=1$, and we are left with only the deduction portion; if $k=0$, then the property tax is completely an excise tax and the full cost (minus deduction) is included. This representation ignores the limit on the exclusion for capital gains taxation on 
housing assets. For practical purposes, we expect that leaving out the limit on capital gains, $\$ 250,000$ for singles and $\$ 500,000$ for married filers, will not change our simulation results appreciably. In principle, we could include this limit in our model, but with no known data source to parameterize this limit, we cannot include it in simulations.

To estimate the excess burden from preferential tax treatment on housing consumption, we start with a standard deadweight loss equation (Rosen, 1979a, Poterba, 1992). The excess burden on housing consumption that results from the tax code is:

$$
\text { DWL / Income }=(1 / 2)\left|\bar{\eta}_{j}\right| s_{y} \sigma_{j}^{2}
$$

where $s_{h}$ represents the share of income spent on housing, and $\sigma_{j}^{2}$ represents the squared value of the change in the cost of housing services induced by differential tax treatment. One departure we make from previous studies is that we relax the assumption that housing supply is perfectly inelastic. Accordingly, we incorporate local housing supply elasticities into our measure of deadweight loss by defining $\bar{\eta}_{j}$ as the harmonic sum of minus the compensated price elasticity of demand, $-\eta^{c d}$, and the local housing supply elasticity, $\eta_{j}^{s}$, or $\bar{\eta}_{j}=-\eta^{c d} \eta_{j}^{s} /\left(-\eta^{c d}+\eta_{j}^{s}\right)$.

\section{Calibrating the Model and Examining its Validity}

\section{A. Parameterization and Calibration}

To make our models useful for simulation, we need to assign values to the parameters using available data and previous work. According to our parameterization, labor receives $s_{w}=75 \%$ of income. 16 percent of income is spent on housing. Another 16 percent is spent on local goods with prices collinear with housing, to simulate differences in costs-ofliving across cities in non-housing goods. We take 67 percent of our households to be itemizers, reflecting their share of income (the raw number is only 27 percent). 10 percent are assumed to be non-itemizers, with the remainder renting. The starting point for our elasticity of employment with respect to local taxes, $\varepsilon$, is taken at -6.0 from Bartik's (1991) meta-analysis of the effect of local taxes on local levels of output and employment, controlling for local public spending. It is also consistent with a fully calibrated model, seen in Albouy and Stuart (2014). As this value is crucial to the locational inefficiency measure, we also consider a conservative value of -1.0 as an alternative.

The marginal federal income tax rate on gross wages is $23.8 \%$ ac- 
cording to TAXSIM (Feenberg and Coutts 1993); this rate is comparable to the empirical tax findings. Adding the marginal payroll tax rate on both the employer and employee sides, net of additional Social Security benefits (Boskin et al. 1987), leads to a higher effective rate of $32.0 \%$. At the state level, the average effective marginal tax rate on wages is 6.2 percentage points, and ranges from 0 in Alaska to $9.0 \%$ in Minnesota.

To calculate the difference in user cost across cities in our sample we use the federal and state tax rates described above, excluding payroll taxes. We apply the tax on income, $\tau_{Y}$, differently than the tax rate that applies to deductions, $\tau_{D}$, according to state tax rules on allowance of the MID. For the property tax rate, $\tau_{P}$, we use the average rate reported at the city level by respondents of the 2007 American Community Survey. We use estimates from Anderson et al. (2007) for the share of mortgage exceeding current law MID limits..$^{20}$ Following Poterba and Sinai, we assume a combined $2.5 \%$ maintenance and depreciation rate, and a risk premium of $2 \%$. We use a mortgage interest rate, $r_{M}$, of $6 \%$, reported as the average interest rate on first lien mortgages for the stock of mortgages in 2007 by the Survey of Consumer Finances (SCF). We also use the 2007 SCF to determine an average loan to value ratio of $0.624 .{ }^{21}$ The risk free rate, $r_{T}$, is the 10 year Treasury bond yield in 2003. The primary difference between our parameterization and Poterba and Sinai (2008a) is that they use individual data from the Survey of Consumer Finances to estimate marginal tax rates. They use these estimates to describe differences across income and age groups, whereas we are primarily interested in geographic differences. We also use the American Community Survey (ACS) for property tax rate estimates, whereas they use the SCF, which does not differentiate across geography. In addition, we use an average capital gain $\pi$ of 0.02 , which we adjust slightly for local differences based on housing price changes between 2000 and 2007.

Our baseline assumption is that, on the margin, property taxes act mostly as excise taxes, so that $k=0.25$. We also show an alternative with $k=1$, which is the pure benefit case. We prefer $k=0.25$ based on the idea that property taxes discourage households from consuming housing more than they discourage them from consuming public services. This appears to be largely true of public services such as education, parks, and public safety, since their consumption depends mainly on the number of individuals, especially children, in the households that live in the community. The assumption appears less true for local 
roads and fire protection, since smaller houses may require fewer roads and fewer firemen, although we expect such effects to be rather minor. We are also unaware of any evidence that property taxes cause households to have fewer children by making housing more expensive. ${ }^{22}$

Our estimates of local housing supply elasticities, $\eta_{j}^{s}$, come from Saiz (2010), who estimates this parameter across metropolitan areas using satellite-generated data on the slope of local terrain and presence of natural boundaries such as bodies of water and wetlands. For the compensated housing demand price elasticity, we use $\eta^{c d}=-0.5$ (Polinsky and Ellwood, 1979), which is conservative relative to recent empirical estimates in Hanson and Martin (in press) and those used in other simulations (Poterba, 1992). We also use these elasticities to adjust estimates of local population responses $\varepsilon^{j}$ to differences in federal taxes, starting from the typical value of -6.0 .

\section{B. Wage and Housing Cost Differentials}

Wage and housing price differentials are estimated using 1\% samples of the American Community Survey from 2005 to 2009 from the Integrated Public Use Microdata Series (IPUMS). Cities are defined at the Metropolitan Statistical Area (MSA) level using 1999 OMB definitions. Consolidated MSAs are treated as a single city (e.g., San Francisco includes Oakland and San Jose), as are the nonmetropolitan areas of each state.

Interurban wage differentials are calculated from the logarithm of hourly wages for full-time workers, ages 25 to 55 . We compute raw differentials across areas and separate the effects explained by observable characteristics, using the residuals to explain the remaining difference. This is done by regressing log wages on city indicators, to identify the location effects, and an extensive set of controls-each fully interacted with gender-for education, experience, race, occupation, industry, and veteran, marital, and immigrant status, to identify the composition effects. The locational wage differentials correspond to those in the model and are interpreted as the causal effect of city $j$ 's attributes on a worker's wage. Identifying these differentials requires that workers do not sort across cities according to their unobserved skills. ${ }^{23}$

Housing values and gross rents reported in the census are used to calculate housing price differentials. To reduce measurement error from imperfect recall or rent control, the sample includes only units that 


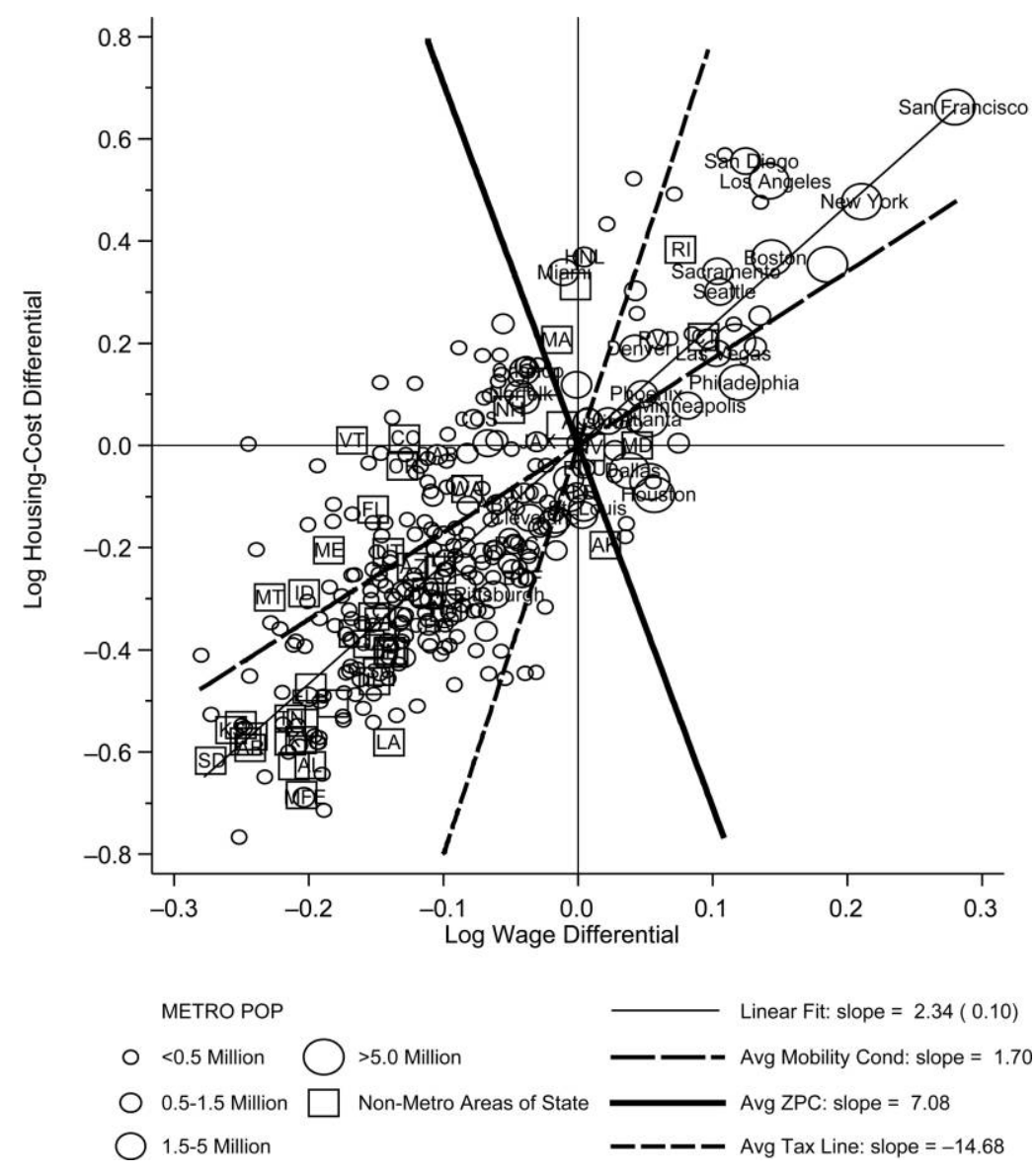

Fig. 3. Locational wage and housing costs across areas, 2007

were acquired in the last ten years. Price differentials are separated into compositional and locational components, and are estimated in a manner similar to wage differentials, using a regression of rents and values on flexible controls-interacted with tenure-for size, rooms, acreage, commercial use, kitchen and plumbing facilities, type and age of building, and the number of residents per room. Proper identification of housing cost differences requires that the average unobserved housing quality does not vary systematically across cities.

Locational wage and housing cost differences across areas are graphed in figure $3 .{ }^{24}$ Panel A of table 1 reports the mean and standard deviations of these differentials, which together with the figures, reveal that 
Table 1

Descriptive Statistics of Differences Across Areas, 2007

\begin{tabular}{lcc}
\hline & $\begin{array}{c}\text { Mean } \\
(1)\end{array}$ & $\begin{array}{c}\text { Std. Dev. } \\
(2)\end{array}$ \\
\hline $\begin{array}{l}\text { Panel A: American Community Survey Data } \\
\text { Standard deviation within MSA }\end{array}$ & -2009 & \\
Log housing cost differences: & 0.706 & 0.042 \\
$\quad$ Raw & & \\
Standard deviation within MSA & 0.0 & 0.340 \\
Log housing cost differences: & 0.706 & 0.042 \\
Raw & & \\
Predicted by location & 0.0 & 0.340 \\
Predicted by composition & 0.0 & 0.345 \\
$\quad$ Standard deviation within MSA & 0.0 & 0.045 \\
Effective property tax rate & 0.819 & 0.076 \\
Panel B: Statistics On Income Data per Capita & 0.010 & 0.004 \\
Filers & & \\
Adjusted gross income & 0.494 & 0.066 \\
Nonwage income & 27,766 & 7,457 \\
Taxes owed & 8,957 & 3,430 \\
Claiming mortgage interest deduction & 3,722 & 1,505 \\
Mortgage interest deduction if claimed & 0.267 & 0.068 \\
Panel C: Tax Data & 11,658 & 3,789 \\
Combined federal tax rate on labor & & \\
Reform federal tax rate on labor & $32.0 \%$ & \\
State sales tax rate & $29.3 \%$ & \\
State income tax rates & $5.5 \%$ & $1.4 \%$ \\
\hline Notes: Amercan Commity Survey data & $4.2 \%$ & $2.4 \%$ \\
\hline
\end{tabular}

Notes: American Community Survey data for 325 metro-level observations, including 50 nonmetro areas of states. Means and standard deviations weighted by population. Statistics on Income data from tax year 2007 ZIP code level file. Panel C tax data from NBER TAXSIM.

most of the average raw wage and housing cost differences across areas are not explainable by observable characteristics, but appear to be due to locational effects.

To check the accuracy of the calibrated model, we make comparisons to measured tax and deduction differentials across metropolitan areas using federal tax data from the IRS ZIP code files in Albouy and Hanson (2013). The IRS ZIP code files are ZIP code level data created from individual tax returns for $2007 .{ }^{25}$ The IRS ZIP code level data allow us to produce measured tax and deduction differences across metro areas by aggregating ZIP code level data to the state and metropolitan area. ${ }^{26}$ The IRS data are beneficial for this purpose as they give 


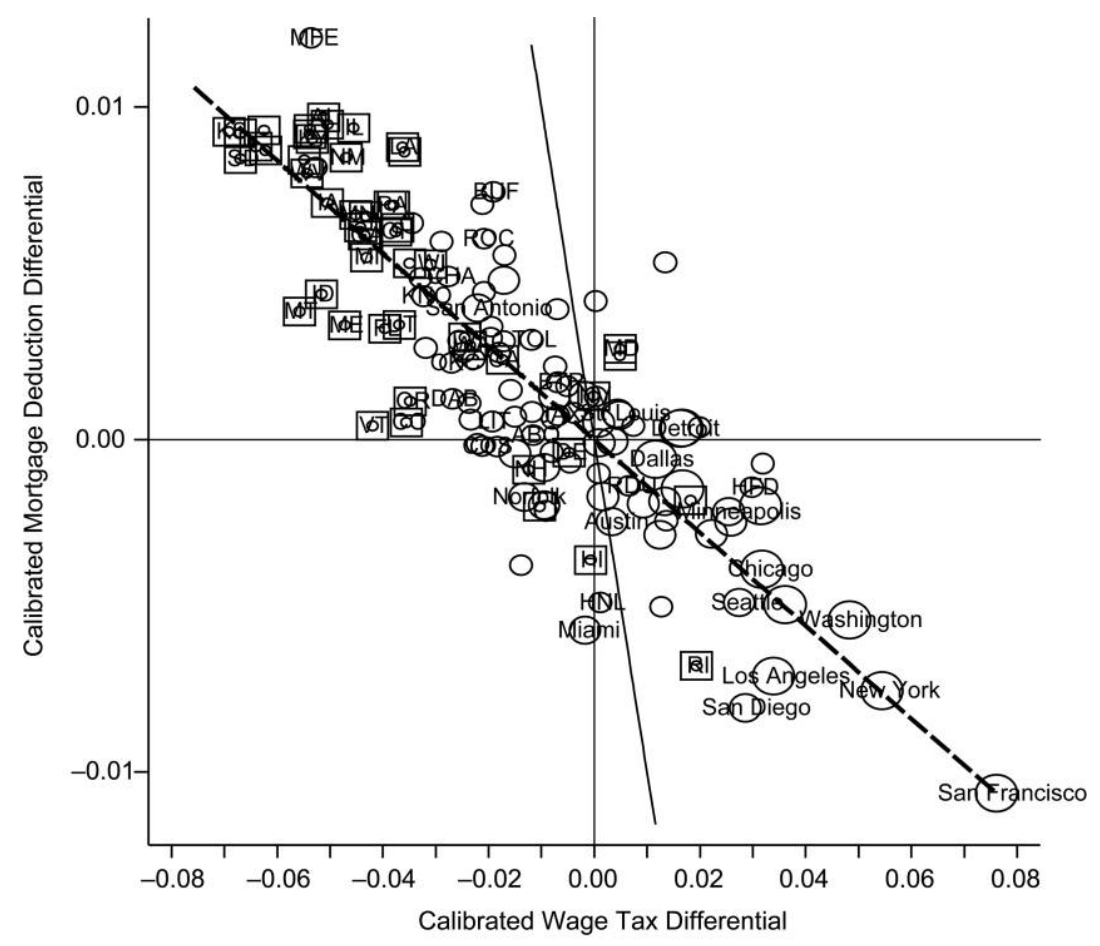

METRO POP

$\circ<0.5$ Million Total Offset: slope $=-1.0$

O $0.5-1.5$ Million

1.5-5 Million

$>5.0$ Million

Non-Metro Areas of State

Fig. 4. Calibrated tax and deduction differentials

actual tax payments and number of claims, but they do not allow us to control for composition differences in the population. For descriptive purposes, Panel B of table 1 shows summary statistics for the IRS data aggregated to the metropolitan area level. The metro area average adjusted gross income for tax filers in our sample is $\$ 27,766$ with a substantial standard deviation of $\$ 7,457$. With the detail of the IRS data we can also see that about $27 \%$ of the tax filers in the sample claim the mortgage interest deduction with an average claim of $\$ 11,658$. The standard deviation on the average mortgage interest deduction is substantial at $\$ 3,789.27$ 
Table 2

Size of Locational Distortions Across Metro Areas, 2007

Standard

Deviation

(1)

Locational tax distortion

Total distortion $\quad 0.026$

Tax distortion from wages alone $\quad 0.035$

Tax distortion from housing benefits alone $\quad 0.010$

Total Tax Distortion after Simulated Reforms

Eliminating mortgage interest deduction $\quad 0.027$

Taxing capital gains on housing 0.028

Eliminating mortgage deduction and taxing capital gains $\quad 0.028$

Tax distortion from wages alone with lower rates $\quad 0.032$

Notes: We consider metropolitan areas as the unit of analysis as they represent areas where residents both live and work. The location distortion measures the impact of taxes on choice of residence across metropolitan areas. The mean distortion will be zero, and standard deviations represent movement across locations.

\section{Simulation Results}

\section{A. Locational and Quantity Tax Distortions}

Figure 4 displays the tax differentials or locational wedges due to wage and housing cost differences across areas, according to equation (1): these are divided into the portion due to higher wages on the horizontal axis, and lower housing costs on the vertical axis. The solid line in the graph shows where the housing tax treatment differential would offset the wage-tax differential one for one. The size of a city's total differential is determined by its distance to the right of or above this line (note the difference in scale).

The standard deviations reported in table 2 reveal that location tax distortions due to housing benefits are indeed smaller than those due to wages. However, as seen in the dashed regression line in figure 4, they are negatively related, as places with higher wages have higher costs, and thus, benefit more from the tax-preferred status of housing, helping to offset the tax differential somewhat. If tax preferences for housing were eliminated, the average tax line in figure 3 would become vertical, as total tax differentials become wage-tax differentials. To the extent that general equilibrium effects can be ignored (our simulations predict they are small), this would increase the size of the total tax differentials.

Table 3 reveals the average size of the housing quantity-tax distortions, expressed as an ad valorem subsidy to consumption. For item- 
Table 3

Housing Consumption Tax Distortions, 2007

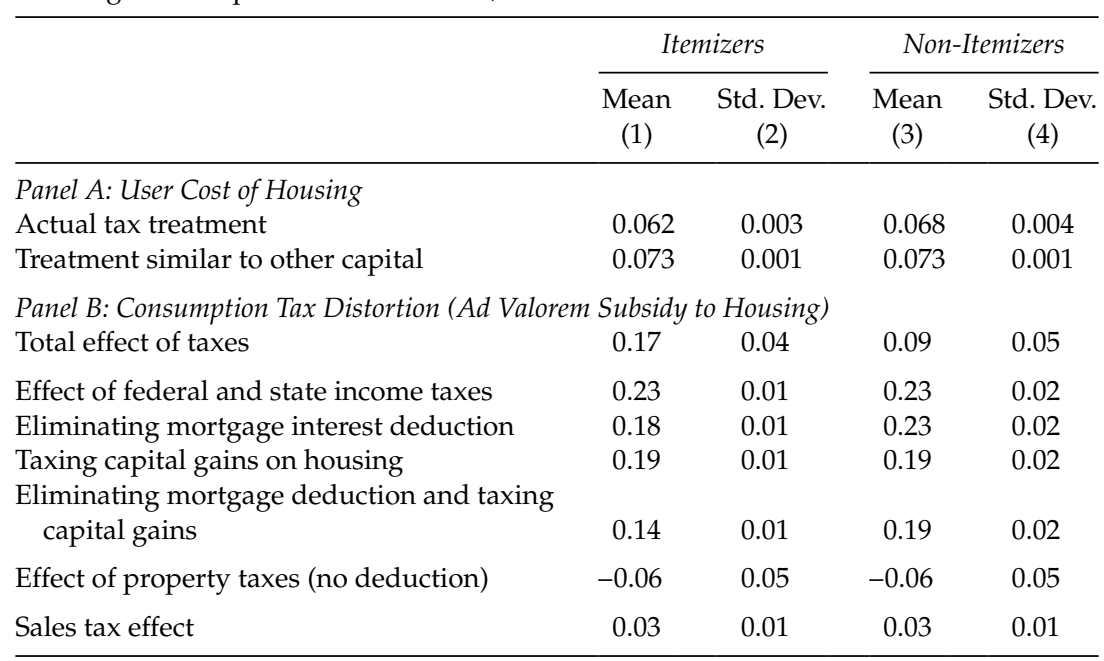

Notes: User cost of housing calculated as in equations (4) and (5). Ad valorem subsidy for housing calculated as in equation (3).

izers, a neutral tax treatment would make the user cost $7.3 \%$, although the actual user cost is typically $6.2 \%$, a $17 \%$ reduction. If we consider the tax distortions individually, benefits in the income tax code create an effective ad valorem subsidy of $23 \%$ on average; property taxes without a deduction create an effective ad valorem tax of $6 \%$. This is offset with the lack of sales taxes, which increase the average effective subsidy by $3 \%$. The net effects are generally smaller for nonitemizers, especially since they cannot itemize property taxes. However, they still benefit from having implicit rents untaxed, which in our sample are rather large, since nonitemizers have greater equity in their homes.

\section{B. Simulated Effects of Tax Distortions across US Cities}

Table 4 reports the size of the quantity effects across select metropolitan areas using variation in state and local taxes, as well as housing supply, which creates the variety of behavioral elasticities in column 1 . The elasticities imply that housing is more responsive to demand in cities like Houston and Greenville, than in Los Angeles and Miami. However, the consumption tax distortions in column 3 are sometimes larger in the less elastic cities, like San Francisco and Salt Lake City. This is due to these cities receiving particularly favorable tax treatment for their large 
capital gains. In the grouping in column 6, we predict that housing consumption per capita is as much as $7 \%$ higher because of tax preferences in Oklahoma City, while it remains nearly unchanged in Miami due to the small elasticity. On average, the typical house is $4 \%$ larger.

Table 4 also reports the predicted effects of location distortions across these metro areas. Population effects are determined by the standard deviation of the tax differentials and the elasticity of population, reported in column 2, which varies because of local elasticities in housing supply. The population effects must average out to zero as they are population-weighted, and have a large standard deviation of $16 \%$. This means an area with a tax differential of one positive standard deviation, or $2.6 \%$ of income, has a long-run population level $16 \%$ lower than it would under a geographically neutral tax system; the opposite is true of areas with negative differentials, which may be seen as subsidies. ${ }^{28}$

\section{Efficiency Cost of Tax Distortions}

Table 5 presents the efficiency costs of tax benefits to housing using the calibrated model and data under a variety of modeling scenarios. In our benchmark case, the deadweight loss from locational inefficiency amounts to about $\$ 26$ billion per year, or $0.22 \%$ of income as shown in table 5 . The overall efficiency cost of tax subsidies for housing is calculated in table 4 for our benchmark case and several alternatives. On average, we find that the typical household consumes housing at a rate approximately $4 \%$ above the efficient level (assuming there are no positive externalities from consuming more housing), creating a welfare loss of $\$ 7$ billion, or $0.06 \%$ of income.

If property taxes are entirely benefit taxes, they do not push houses to be small. In this case, reported in column 2, houses are on average $7.4 \%$ too large, and the deadweight loss from quantity inefficiency increases to $\$ 19$ billion or $0.16 \%$ of income. If we ignore the reduction in tax burdens due to the deductibility of property taxes, this would reduce locational inefficiency very slightly.

In column 3, we ignore the tax benefits given to capital gains in housing; the deadweight loss in location inefficiency increases to $\$ 30$ billion, or $0.25 \%$ of income. This is because places with higher wages benefit most from this exemption. Looking at quantity inefficiency, this decreases, since households have less of an incentive to invest in housing. Ignoring state income and sales taxes would also produce smaller measures of inefficiency, since these taxes generally exacerbate preexisting distortions. The effects are generally rather small. 


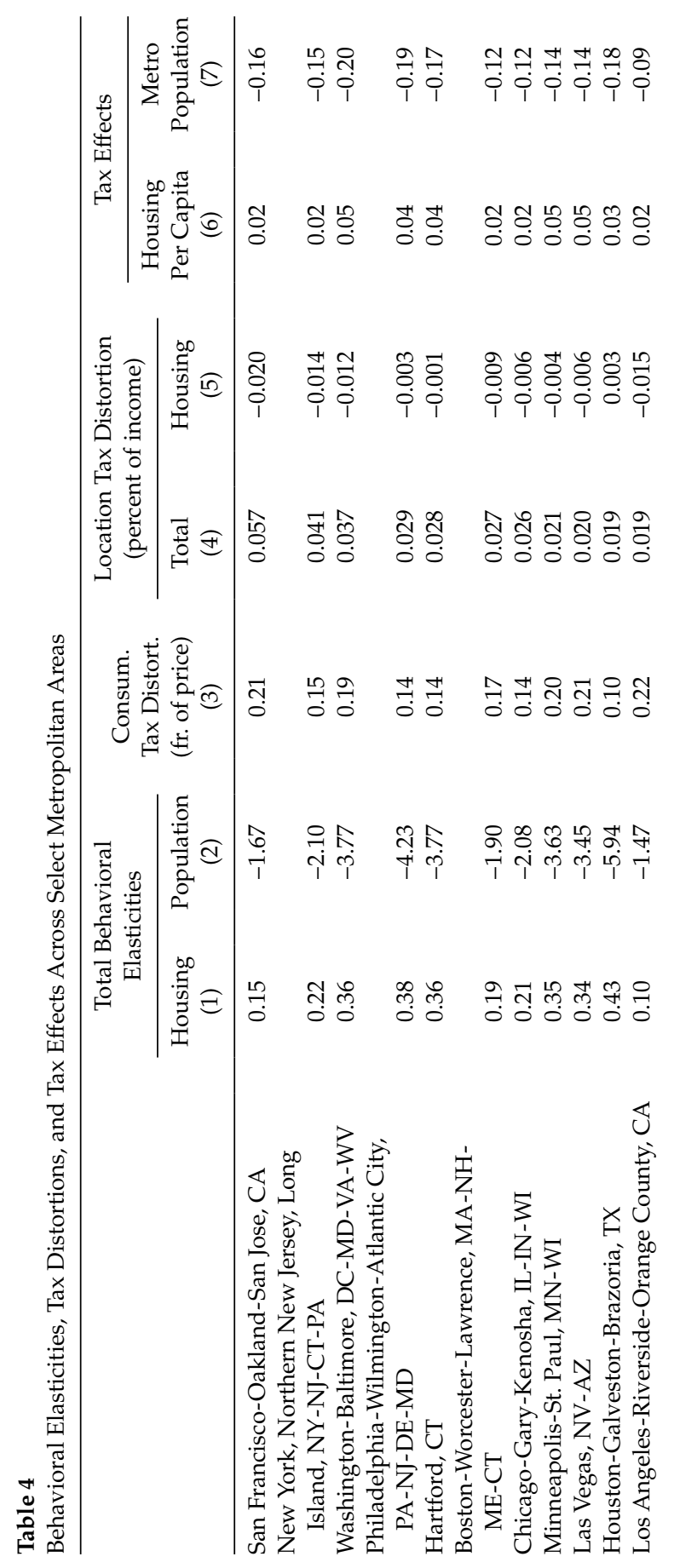




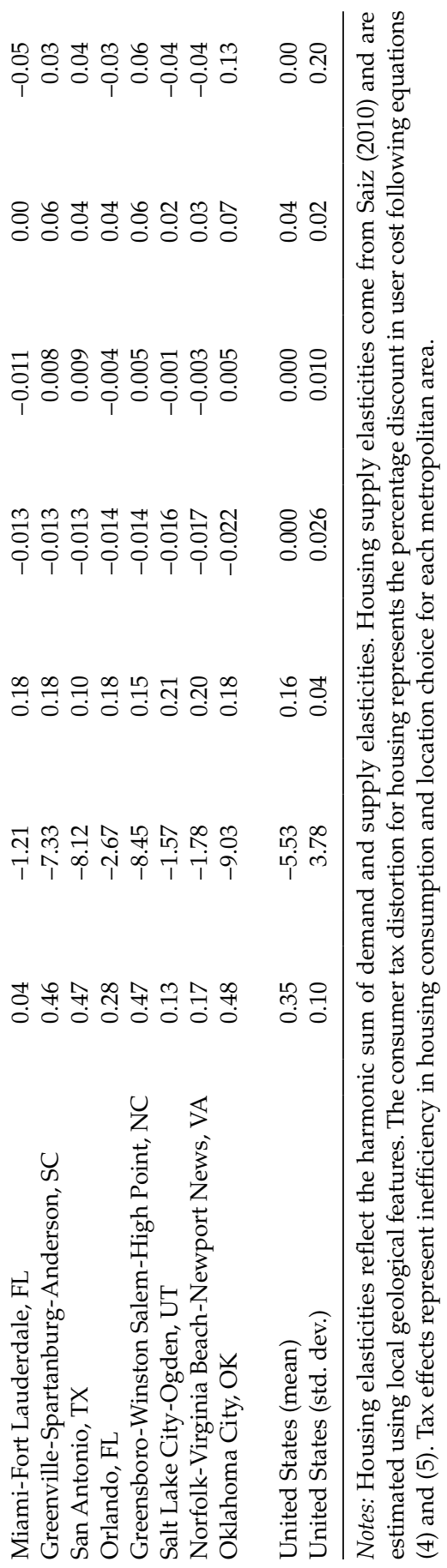




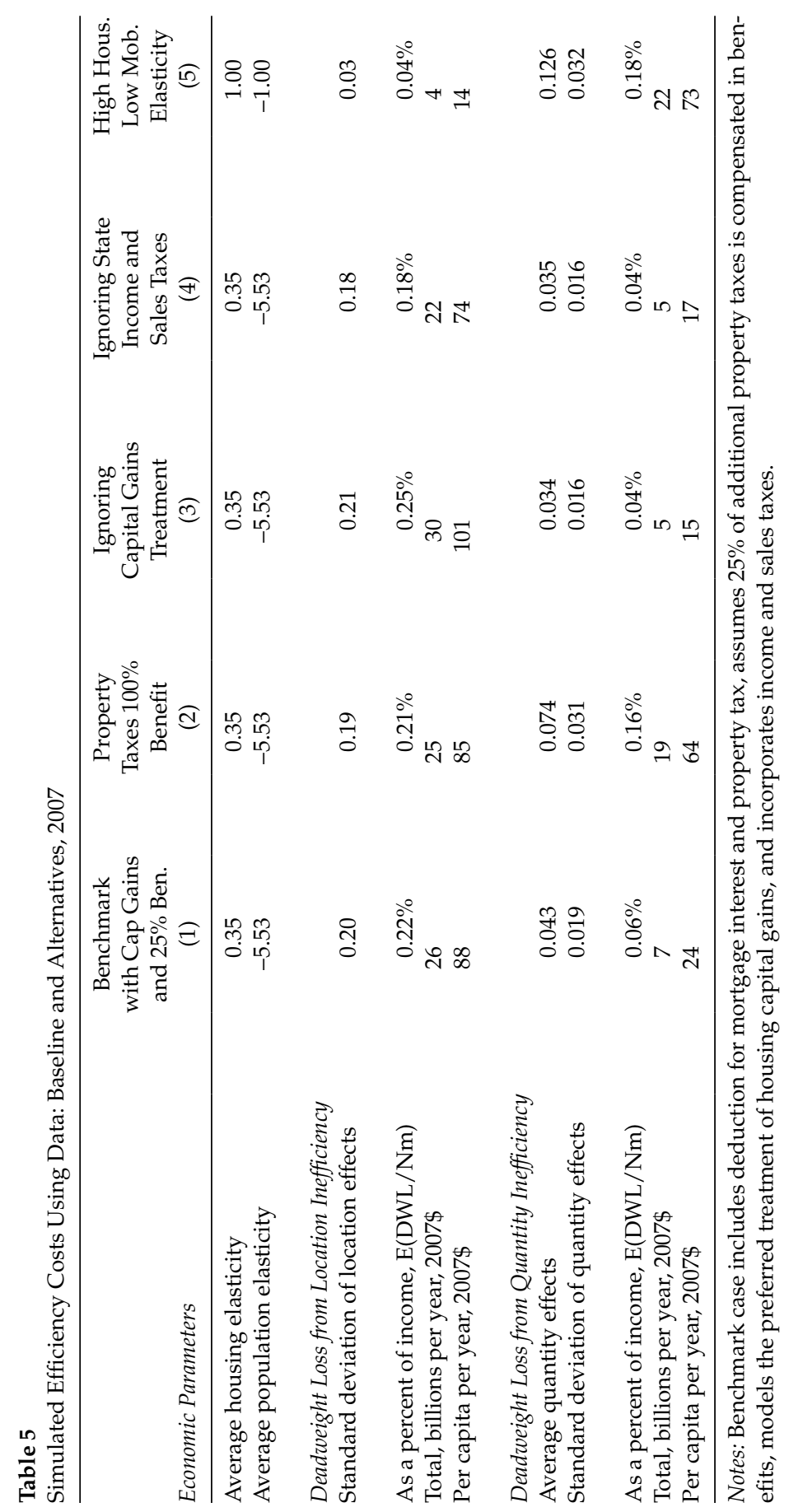


Naturally, the locational deadweight loss is sensitive to the elasticity of population: if we use -1 for all of the cities, deadweight loss falls to only $\$ 4$ billion, or $0.04 \%$ of income. Assuming a compensated price elasticity of -1 across cities (say with perfectly elastic supply across cities), results in houses being 13\% too large, and tripling the deadweight loss from quantity inefficiency.

Our benchmark estimates of the efficiency costs in housing quantity are smaller than Poterba (1992) who estimates in 1990 that housing is overconsumed by between $12.4 \%$ and $23.2 \%$, depending on taxpayer income. Our estimates are smaller due to lower interest rates, lower marginal tax rates, and a lower compensated demand elasticity (Poterba chooses -0.80$)$. Furthermore, we treat the property tax as distortionary in the opposite direction and incorporate finite supply elasticities. Even when we use a similar elasticity to Poterba (1992), our results are about half the size of his estimates.

\section{The Simulated Effects of Federal Tax Reforms}

Table 6 reports the simulated effect of several federal tax reforms, such as eliminating housing tax deductions, eliminating the capital gains exemption, or indexing taxes to local costs-of-living and wage levels. ${ }^{29}$ Column 1 reports that eliminating the mortgage interest and property tax deductions would lower quantity inefficiency costs from $0.06 \%$ to $0.03 \%$ of income. This would be offset by a slight rise in location inefficiency costs. The net effect would be to reduce the total deadweight loss by about $\$ 4$ billion a year.

Taxing capital gains on housing would produce no net efficiency improvement, since the reduction in quantity efficiency would be offset by an equally large increase in location efficiency. If deductions are already eliminated, taxing capital gains appears to make the economy slightly less efficient.

Somewhat surprisingly, we find that repealing all of the tax advantages of housing would lead to greater total deadweight loss than the existing tax system. Quantity inefficiencies fall from $0.06 \%$ to $0.2 \%$, as households consume houses that are inefficiently small. Meanwhile, the locational inefficiency would rise substantially, from $0.22 \%$ to $0.39 \%$ of income, as households in high-wage productive areas would no longer receive tax breaks for their higher housing costs.

One possible shortcoming of these simulations is that they hold tax 


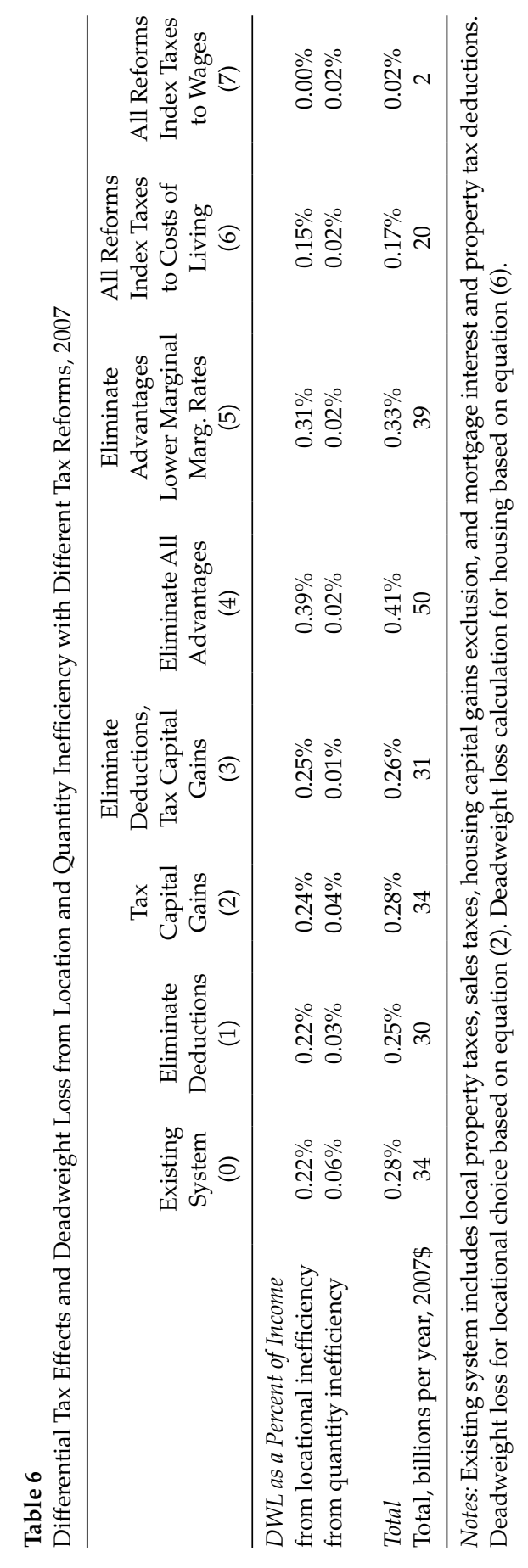


rates fixed. If total revenues remained constant, marginal tax rates on labor income could be reduced when housing tax benefits are eliminated. If we were to do this, we find that this would improve locational efficiency substantially relative to the scenario with no rate cuts. Even with these improvements, the overall costs are still higher than in the benchmark case.

These static simulations so far suggest that the most efficient policy would be to eliminate the housing and property tax deductions. As we mentioned earlier, it may be more efficient to completely undo the preferential treatment of housing, and to index income to local costs of living or wages. We do this in columns 6 and 7, cutting rates to take into account the tax savings from taxing housing more heavily. Indexing income to local costs of living would indeed lead to higher overall efficiency: houses would be only slightly too small, due to the property tax, and would be disproportionately located in high quality-of-life areas. The overall cost would be only $0.17 \%$ of income. With an ideal wage indexation, the location inefficiencies would be eliminated entirely, leading to the most efficient outcome.

The policy change simulations are sensitive to alternative calibrations (e.g., using different elasticities). Nonetheless, indexing income taxes to local wage levels and eliminating the housing tax preferences is still the reform that reduces deadweight loss the most. It is worth noting that our model does not consider the interaction between housing tax benefits and the alternative minimum tax (AMT). Presumably, the presence of the AMT would reduce the size of the changes we estimate, as filers subject to the AMT are already subject to rollbacks on most deductions. ${ }^{30}$

\section{Conclusion}

Housing tax benefits affect not only the quantity of housing people consume, but where that housing is located. Furthermore, tax benefits in the income tax code must be framed relative to other distortions. In affecting the quantity of housing, benefits work against the property tax, more than correcting it, causing houses to be too large rather than too little. In affecting the location of housing, benefits work to help locate workers in high-cost areas. Since high-cost areas tend to be high-wage areas, they typically help to correct the disincentive created by the tax code to live and work in high-wage areas. In this case, benefits to housing are much smaller than the effect they work against.

An upshot of these other distortions is the somewhat surprising conclusion that housing benefits are not as distortionary as previous anal- 
ysis suggests. Reducing benefits improves quantity efficiency, but the value of this improvement is somewhat small, mainly because of limited elasticity in the demand and supply of housing. Furthermore, if marginal tax rates are not reduced, location decisions will be made less efficient. If the population truly is very responsive to these differences over the long run, these efficiency costs may be quite high, since they cause workers to work in areas where they are less productive.

While we find housing-tax benefits make location choices more efficient, this does not negate other arguments for policy reform. These deductions (especially for mortgage interest) have long been criticized for being expensive, regressive, and not well targeted to their stated goal of subsidizing home ownership. These criticisms all have their merit. It is also important to raise the point that gains to locational efficiency from housing tax benefits could be reproduced and applied to a larger fraction of the population by indexing taxable income to local cost of living. Such a system could be improved by adjusting costs for local quality of life, which would be equivalent to indexing by local wage levels. Lastly, we should state that there many other distortions that may cause houses to be too big or people to live in the wrong place, such as subsidized transportation costs and fiscal zoning. We leave such interesting dimensions to future research.

\section{Endnotes}

For acknowledgments, sources of research support, and disclosure of the authors' material financial relationships, if any, please see http:/ / www.nber.org/chapters/c13054.ack.

1. Homeowners can also deduct up to $\$ 100,000$ in home equity secured debt, effectively pushing the lending cap to $\$ 1.1$ million.

2. See Burman and Phaup (2012) for a discussion of how much additional revenue would actually be collected if these and other tax expenditures were eliminated. They point out that revenue depends on the behavioral response of taxpayers and the interaction with other aspects of the tax code (rates, itemization, and other deductions).

3. All dollar amounts of tax expenditure come from the "Analytical Perspectives, Budget of the United States Government, Fiscal Year 2013" and reflect estimates of the foregone revenue from 2014 tax collection.

4. The purchase of materials for home improvements is taxed, but labor that is put into home improvements is not taxed.

5. The Commission suggested transforming the mortgage interest deduction to a $12 \%$ tax credit limited to mortgages less than $\$ 500,000$. The Commission also recommended eliminating itemized deductions, which would include the deduction for property taxes paid. Green and Vandell (1999) simulate the effects of a revenue neutral change from the mortgage interest and property tax deductions to a housing tax credit and find that such a policy would increase aggregate home ownership rates.

6. Percent of tax filers claiming the MID is calculated using 2011 IRS statistics of income tables for total number of tax returns and number of returns that include an MID claim. The 2011 tax year represents a low point in MID claims for the last 5 years, with the claim rate reaching as high as $28.5 \%$ of tax filers in 2007. 
7. Previous studies consider how eliminating deductions would affect revenues and incentives (Poterba and Sinai, 2011), as well as the user cost of housing (Anderson et al. 2007, Poterba and Sinai 2008), how switching to a consumption based tax would impact the housing market in general (Bruce and Holtz-Eakin, 1999), and how housing might be treated by a national retail sales tax (Feenberg, Mitrusi, and Poterba 1997).

8. This figure is substantially smaller than recent estimates in Hanson and Martin (in press) that account for the full range of housing consumption distortions by examining the effect of mortgage interest deductibility on the amount of mortgage interest deducted. They estimate the annual deadweight loss from housing consumption to be $\$ 16-36$ billion.

9. We then are just modeling firms that produce tradable goods. This simplification works well when housing is made with land and mobile capital, without labor. Albouy (2009a, 2009b) presents a fuller model. He demonstrates that when cities are good at producing housing, the model will produce the opposite effect on prices and wages than when they are good at producing tradable goods. Without land prices, the two are observationally impossible to disentangle, but for the purpose of examining tax policy, this assumption does not affect the model's predictions.

10. This is not exactly true with either a progressive or regressive tax, but we can easily redefine an "average city" as one paying an amount of taxes without much loss of generality. Alternatively, we may assume that tax revenues are redistributed in equal lump sum payments, and define an average city as one that pays on net zero dollars to the federal government.

11. By symmetry, presumably there is also a lower productivity city than Nashville, which will gain population, and see housing prices and wages rise. The wage predictions rely on the assumption that there are fixed factors in production and that agglomeration economies in production are fairly weak.

12. If this indexation scheme applied to all workers then the equilibrium would move back to $E_{0}^{C}$ In this. case, the index would need to take into account the change in equilibrium wages.

13. A similar argument holds for neighborhoods within a city. If wage earners face equal commute times in Arlington and Bethesda, but Bethesda offers better quality of life, then tax benefits will artificially inflate housing prices and population numbers there. As noted by Wildasin (1986), taxes on labor lower the value of time of workers, causing them to commute for too long, leading to sprawl. Tax benefits to housing may mitigate this effect by increasing the amount of investment into structures located more centrally. This may be seen by taking the opposite results of Brueckner and Kim (2003) for the property tax, which they find would differentially reduce investments in central structures. It is unclear whether this effect would reduce sprawl, since subsidies increase the demand for those structures. In addition, denser multifamily buildings that tend to be located centrally are usually rented and thus do not benefit from housing tax benefits like the mortgage interest and property tax deductions (see Glaeser 2011).

14. We do not consider other fees that may act like taxes on a home purchase, such as closing costs due at the time of purchase. In general, the fraction of closing costs that represent fees that act like taxes is small compared to those that represent services. Title search and insurance fees typically represent the largest portion of closing costs, which offer buyers the service of ensuring that there are no other liens, easements, or other restrictions on the property - a service to buyers. Treatment of closing costs varies in the literature from being considered part of the equity financed portion of the user cost (Genesove and Mayer, 1997) to being a separate parameter affecting housing supply (Yinger, 1981).

15. See Rosen (1979a, 1979b, 1985), Poterba (1984, 1992), Green and Vandell (1999), Glaeser and Shapiro (2003), Himmelberg, Mayer and Sinai (2005), and Anderson et al. (2007) for variants of the user-cost model.

16. Berkovoc and Fullerton (1992) model tax incentives in general equilibrium setting and present evidence that ownership is determined primarily by demographics, while the amount of housing consumed depends on its relative price. They demonstrate that taxing imputed rent reduces undiversified risk faced by households, and can actually increase home ownership rates.

17. Our simulations account for differences in state mortgage interest deductibility. 
18. The literature on the behavioral response to property taxes focuses on the mobility (Fox, Herzog, and Schlottman (1989), O'Sullivan, Sexton, and Sheffrin (1995), Knapp, White, and Clark (2001), Shan (2010)), property improvement (Oates and Schwab (1997), Anderson (2008), and urban sprawl (Song and Zenou (2006), Banzhaf and Lavery (2010)). See Deskins and Fox (2008) for a recent review of the literature on the behavioral response to property taxation; there is also an extensive empirical literature on the relationship between property tax and home values. See Palmon and Smith (1998) for an excellent example and Sirmans, Gatzlaff, and Macpherson (2008) for a recent review of the capitalization literature.

19. In our simulations, tax rates include both state and federal income taxes.

20. We use the variation across cities in their sample for all caps. They use data on actual mortgages originated in 2003 to calculate values of the $s$ parameter.

21 . The loan to value ratio is the average family holdings of debt on mortgages $(\$ 149,500)$ plus the debt holdings on home equity lines of credit $(\$ 39,200)$. We divide this by the average asset value of primary residence $(\$ 302,400)$.

22. If anything, we might guess that higher property tax rates increase the amount of local redistribution through public services from households with no or few children to households with many children.

23. In reality, workers do not all have the same endowments and tastes or pay the same marginal tax rate, nor are they equally sensitive to productivity differences. However, as shown in Albouy (2008b), workers with different tastes and endowments can be aggregated without serious complications, so long as each is weighted by their share of income (which we do, although it has little impact on the estimates).

24. Appendix Figure A1 displays wage and housing cost differences explained by observable worker and housing composition.

25. These data are generated from the universe (the Individual Master File System) of all Form 1040, 1040A, and 1040EZ filed with the IRS between January 1, 2008, and December 31,2008. The IRS determines the ZIP code of each taxpayer using what is reported on tax forms, and does not make any attempt to correct invalid ZIP codes or impute missing ZIP codes. ZIP codes with fewer than ten returns are not included in the data.

26. We allocate ZIP code areas to MSAs and nonmetro areas of states using the MABLE/GeoCorr2K database available online at: http://mcdc2.missouri.edu/websas/ geocorr2k.html. The majority of ZIP codes (over 83\%) have complete overlap with an MSA or nonmetro area; we allocate the IRS ZIP code data for ZIP codes with partial overlap to MSAs based on the population overlap between the two areas.

27. As predicted, we found the relationship between taxes and wage levels to be positive and convex, reflecting progressivity in the tax code. The slope of this relationship is 0.252 at the average, which is statistically indistinguishable from the calibrated tax rate of 0.238 . This shows that on average, our calibration fits the measured data quite well.

28. If estimated rather than calibrated tax differentials are used, this increases to $17 \%$.

29. We do not run simulations for taxing imputed rents. We found that incorporating the taxation of imputed rent could actually decrease the user cost of housing using the fomula provided by Poterba and Sinai (2011). This is because of their conclusion that user costs are reduced even further from capital gains and the implicit tax subsidy to the mortgage premium, due to prepayment and foreclosure risk. We are less sure these conclusions would hold in a more general equilibrium setting.

30. Our reforms do not take into account changes in extensive and intensive labor supply from labor market participation and hours worked. Simply eliminating the tax benefits to housing should in principle lower (compensated) labor supply, since the return to working and buying housing consumption should fall. A compensating tax cut on labor income should undo this labor supply response, and possibly push it in a positive direction by increasing consumption efficiency. This ignores the complementarity between housing and leisure. Presumably, housing and leisure are complements, since housing should aid in (or require) household production by making it more desirable to cook at home and do housework for a larger house. In that case, reducing housing quantities could improve efficiency in the labor market by lowering the value of leisure. Following 
the insight of Corlett and Hague (1953), it would then be efficient to tax housing more heavily than other goods, which are less of a complement to leisure.

\section{References}

Albouy, David. 2008. "Are Big Cities Bad Places to Live? Estimating Quality of Life across Metropolitan Areas." NBER Working Paper No. 14472. Cambridge, MA: National Bureau of Economic Research.

$\rightarrow-$ 2009a. "The Unequal Geographic Burden of Federal Taxation." The Journal of Political Economy 17 (4): 635-67.

- 2009b. "What Are Cities Worth? Land Rents, Local Productivity, and the Value of Amenities." NBER Working Paper No. 14981. Cambridge, MA: National Bureau of Economic Research.

Albouy, David, and Andrew Hanson. 2013. "The Geographic Incidence and Welfare Effects of Federal Tax Reform." Unpublished manuscript.

Albouy, David, and Bryan Stuart. 2013. "Urban Population and Amenities." Unpublished manuscript.

$\rightarrow$ Anderson, John, Jeffrey Clemens, and Andrew Hanson. 2007. "Capping the Mortgage Interest Deduction." National Tax Journal 60 (4): 769-85.

Anderson, Nathan. 2008. "Property Tax Exemptions for Residential Capital Investment." State Tax Notes 47 (5): 355-73.

$\rightarrow$ Banzhaf, Spencer, and Nathan Lavery. 2010. "Can the Land Tax Help Curb Urban Sprawl? Evidence from Growth Patterns in Pennsylvania." Journal of Urban Economics 67 (2): 169-79.

Bartik, Timothy J. 1991. Who Benefits from State and Local Economic Development Policies? Kalamazoo, MI: Upjohn Institute.

Bartlett, Bruce. 2013. "The Sacrosanct Mortgage Interest Deduction." New York Times, August 6.

$\rightarrow$ Berkovoc, James, and Don Fullerton. 1992. "A General Equilibrium Model of Housing, Taxes, and Portfolio Choice." Journal of Political Economy 100 (2): 390-429.

Boskin, M.J., Kotlikoff, L.J., Puffertt, D.J., Shoven, J.B. 1987. “Social security: A financial appraisal across and within generations." National Tax Journal 40, 19-34.

$\rightarrow$ Bruce, Donald, and Douglas Holtz-Eakin. 1999. “Fundamental Tax Reform and Residential Housing." Journal of Housing Economics 8 (4): 249-71.

$\rightarrow$ Brueckner, Jan, and Hyun-A Kim. 2003. "Urban Sprawl and the Property Tax." International Tax and Public Finance 10 (1): 5-23.

Burman, Leonard, and Marvin Phaup. 2012. "Tax Expenditures, the Size and Efficiency of Government, and Implications for Budget Reform." In Tax Policy and the Economy, vol. 26, edited by Jeffrey R. Brown, 93-124. Chicago: University of Chicago Press.

$\rightarrow$ Corlett, W. J., and D. C. Hague. 1953. "Complementarity and the Excess Burden of Taxation." Review of Economic Studies 21 (1): 21-30.

Deskins, John, and William Fox. 2008. "Measuring Behavioral Responses to the Property Tax." In Challenging the Conventional Wisdom on the Property Tax, edited by R. Bahl, J. Martinez-Vazquez, and J. Youngman. Lincoln Institute of Land Policy, 2010.

$\rightarrow$ Feenberg, Daniel, and Elisabeth Coutts. 1993. "An Introduction to the TAXSIM Model." Journal of Policy Analysis and Management 12(1): 189-194. 
Feenberg, Daniel, Andrew Mitrusi, and James Poterba. 1997. “Distributional Effects of Adopting a National Retail Sales Tax." In Tax Policy and the Economy, vol. 11, edited by James M. Poterba, 49-90. Cambridge, MA: MIT Press.

$\rightarrow$ Fox, William, Henry Herzog, and Alan Schlottman. 1989. "Metropolitan Fiscal Structure and Migration." Journal of Regional Science 29 (4): 523-36.

$\rightarrow$ Genesove, David, and Christopher Mayer, 1997. "Equity and Time to Sale in the Real Estate Market." American Economic Review 87 (3): 255-69.

$\rightarrow$ Glaeser, Edward. 2011. "Rethinking the Federal Bias Toward Home Ownership." Cityscape: A Journal of Policy Development and Research 13 (2): 5-37.

Glaeser, Edward, and Jesse Shapiro. 2003. "The Benefits of the Home Mortgage Interest Deduction." In Tax Policy and the Economy, vol. 17, edited by James M. Poterba, 37-82. Cambridge, MA: MIT Press.

Green, Richard 2011. "Testimony of Richard K. Green to US Senate Finance Committee." October 6. http://www.finance.senate.gov/imo/media/doc/ Testimony $\% 20$ of $\% 20$ Richard $\% 20$ K $\% 20$ Green $\% 20$ to $\% 20$ US $\% 20$ Senate $\% 20$ Finance\%20Committee\%20October\%206\%2020111.pdf.

Green, Richard K., and Andrew Reshovsky. 1999. "Using Tax Policy to Subsidize Home Ownership." In Public Spending and Incentives for Community Development Federal Reserve Bank of Boston-Aspen Institute, edited by A. Stager. Washington, DC: Aspen Institute.

$\rightarrow$ Green, Richard, and Kerry Vandell. 1999. "Giving Households Credit: How Changes in the US Tax Code Could Promote Home Ownership." Regional Science and Urban Economics 29 (4): 419-44.

$\rightarrow$ Gyourko, Joseph, and Todd Sinai. 2003. "The Spatial Distribution of HousingRelated Ordinary Income Tax Benefits." Real Estate Economics 31 (4): 527-75.

- 2004. "The (Un)Changing Geographical Distribution of Housing Tax Benefits: 1980-2000." Tax Policy and the Economy 18: 175-208.

Hall, Robert. 1996. "The Effects of Tax Reform on Prices and Asset Values." In Tax Policy and the Economy, vol. 10, edited by James M. Poterba, 71-88. Cambridge, MA: MIT Press.

$\rightarrow$ Hanson, Andrew. 2012. "Size of Home, Home Ownership, and the Mortgage Interest Deduction." Journal of Housing Economics 21 (3): 195-210.

Hanson, Andrew and Hal Martin, in press. "Housing Market Distortions and the Mortgage Interest Deduction." Forthcoming in Public Finance Review.

$\rightarrow$ Harberger, Arnold. 1964. "The Measurement of Waste." American Economic Review 54 (3): 58-76.

$\rightarrow$ Himmelberg, Charles, Christopher Mayer, and Todd Sinai. 2005. "Assessing High House Prices: Bubbles, Fundamentals, and Misperceptions." Journal of Economic Perspectives 19 (4): 67-92.

$\rightarrow$ Knapp, Thomas, Nancy White, and David Clark. 2001. "A Nested Logit Approach to Household Mobility." Journal of Regional Science 41 (1): 1-22.

$\rightarrow$ Mieskowski, Peter. 1972. "The Property Tax: An Excise Tax or a Profits Tax?" Journal of Public Economics 1 (1): 73-96.

$\rightarrow$ Mills, Edwin, 1987. "Has the United States Overinvested in Housing?" AREUEA Journal 15(1): 601-616.

Oates, Wallace, and Robert Schwab, 1997. “The Impact of Urban Land Taxation: The Pittsburgh Experience." National Tax Journal 50 (1): 1-21.

$\rightarrow$ O'Sullivan, Arthur, Terri Sexton, and Steven Sheffrin. 1995. "Property Taxes, Mobility, and Home Ownership." Journal of Urban Economics 37 (1): 107-29.

$\rightarrow$ Palmon, Oded, and Barton Smith. 1998. "New Evidence on Property Tax Capitalization." Journal of Political Economy 106 (5): 1099-111.

Pew Research Center, 2012. Deep Divisions over Debt Reduction Proposals, Oc- 
tober 12. http:/ / www.people-press.org/2012/10/12/deep-divisions-over -debt-reduction-proposals/.

$\rightarrow$ Polinsky, A. Mitchell and David T. Ellwood. 1979. "An Empirical Reconciliation of Micro and Grouped Estimates of the Demand for Housing." The Review of Economics and Statistics: 61(2): 199-205.

$\rightarrow$ Poterba, James M. 1984. "Tax Subsidies to Owner-Occupied Housing: An Asset Market Approach." Quarterly Journal of Economics 99 (4): 729-52.

$\rightarrow-1992$. "Taxation and Housing: Old Questions, New Answers." American Economic Review 82 (2): 237-42.

$\rightarrow$ Poterba, James, and Todd Sinai. 2008. “Tax Expenditures for Owner-Occupied Housing: Deductions for Property Taxes and Mortgage Interest and the Exclusion of Imputed Rental Income." American Economic Review 96 (2): 84-89.

$\rightarrow-$. 2011. "Revenue Costs and Incentive Effects of the Mortgage Interest Deduction for Owner-Occupied Housing." National Tax Journal 64 (2): 531-64.

Pulsenomics. 2012. September 2012 Home Price Expectations Survey. Press release, September 20. https://pulsenomics.com/uploads/Sep2012_ZHPES_Press _Release_Final.pdf.

$\rightarrow$ Roback, Jennifer. 1982. "Wages, Rents, and the Quality of Life." The Journal of Political Economy 90 (4): 1257-78.

$\rightarrow$ Rosen, Harvey. 1979a. "Housing Decisions and the US Income Tax: An Econometric Analysis." Journal of Public Economics 11 (1): 1-23.

$\rightarrow-1$. 1979b. "Owner Occupied Housing and the Federal Income Tax: Estimates and Simulations." Journal of Urban Economics 6 (2): 247-66.

- 1985. "Housing Subsidies: Effects on Housing Decisions, Efficiency, and Equity." Handbook of Public Economics, Vol. 1, edited by Alan J. Auerbach and Martin Feldstein, pp. 375-420. Amsterdam: Elsevier Science Publishers B.V.

Rosen, Sherwin. 1979. “Wages-Based Indexes of Urban Quality of Life.” In Current Issues in Urban Economics, edited by P. Mieszkowski and M. Straszheim. Baltimore: Johns Hopkins University Press.

$\rightarrow$ Saiz, Albert. 2010. "The Geographic Determinants of Housing Supply." Quarterly Journal of Economics 125 (3): 1253-96.

$\rightarrow$ Shan, Hui. 2010. "Property Taxes and Elderly Mobility." Journal of Urban Economics 67 (2): 194-205.

Sinai, Todd, and Joseph Gyourko. 2004. "The (Un)Changing Geographical Distribution of Housing Tax Benefits: 1980-2000." In Tax Policy and the Economy, vol. 18, edited by James M. Poterba, 175-208. Cambridge, MA: MIT Press.

Sirmans, Stacy, Dean Gatzlaff, and David Macpherson. 2008. "The History of Property Tax Capitalization in Real Estate." Journal of Real Estate Literature 16 (3): 327-43.

$\rightarrow$ Song, Yan, and Yves Zenou, 2006. "Property Tax and Urban Sprawl: Theory and Implications for US Cities." Journal of Urban Economics 60 (3): 519-34.

$\rightarrow$ Wildasin, David E. 1980. "Locational Efficiency in a Federal System." Regional Science and Urban Economics 10 (November): 453-71.

$\rightarrow-1986$. "Spatial Variation of the Marginal Utility of Income and Unequal Treatment of Equals" Journal of Urban Economics 19 (1):125-129.

$\rightarrow$ Yinger, John. 1981. "A Search Model of Real Estate Broker Behavior." American Economic Review 71 (4): 591-605.

$\rightarrow$ Zodrow, George. 2001. “The Property Tax as a Capital Tax: A Room with Three Views." National Tax Journal 54 (1): 139-56. 


\section{Appendix}

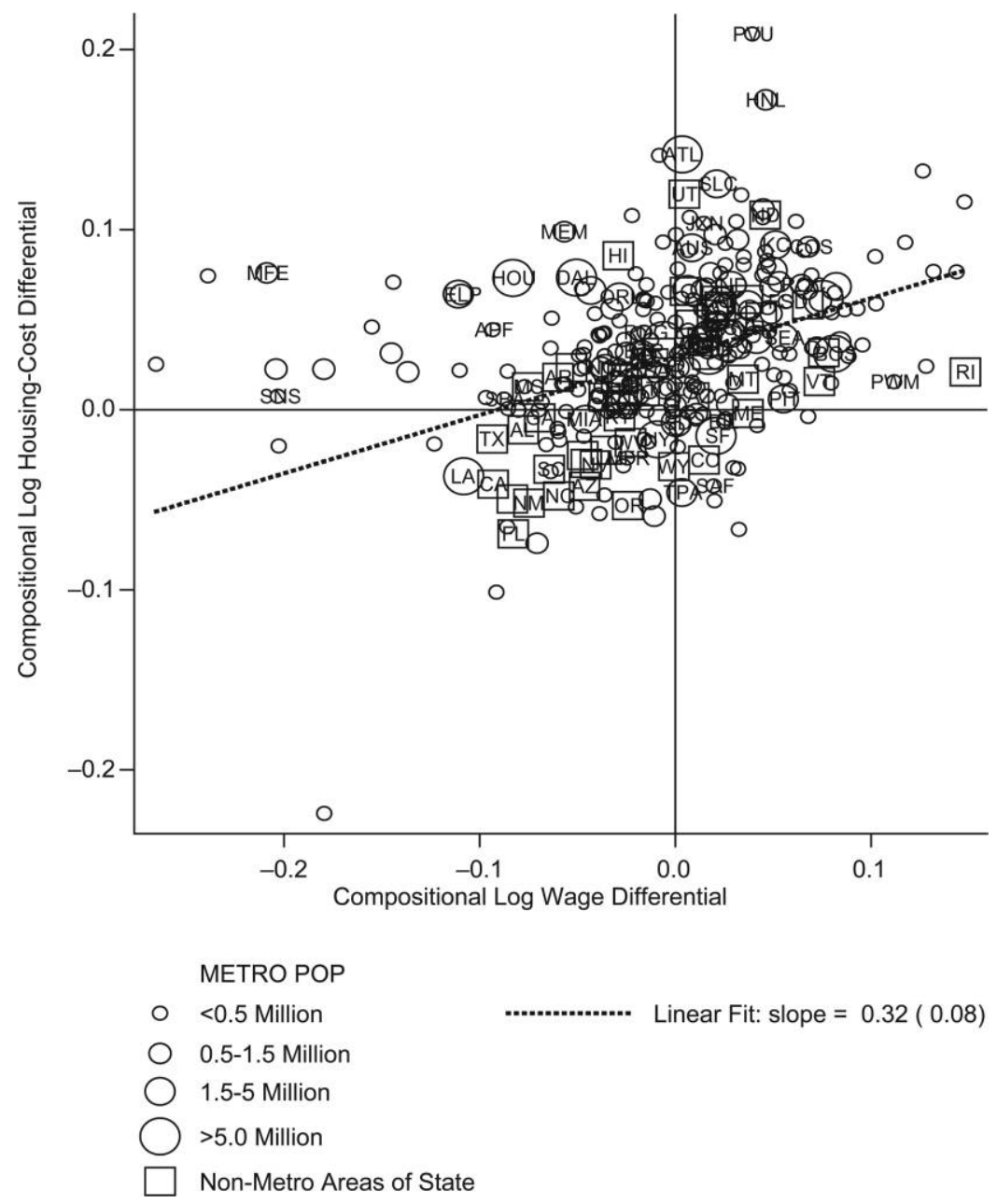

Fig. A1. Compositional wage and housing costs across areas, 2007 